Online di : http://ejournal3.undip.ac.id/index.php/jnc/

\title{
HUBUNGAN ASUPAN ZAT BESI HEME, ZAT BESI NON-HEME DAN FASE MENSTRUASI DENGAN SERUM FERITIN REMAJA PUTRI
}

\author{
Lia Andriani Titik Arima, Etisa Adi Murbawani", Hartanti Sandi Wijayanti \\ Departemen Ilmu Gizi, Fakultas Kedokteran, Universitas Diponegoro \\ Jln. Prof. H. Soedarto, SH., Semarang, Telp (024) 76402881, Email : dept-gizi@ fk.undip.ac.id
}

\begin{abstract}
Background : Adolescent girls in Indonesia have low iron intake where iron source is dominated by non-heme intake. Biovailability of non-heme iron is influenced by substances that inhibit absorption this increase risk of iron deficiency. This study aimed to analyze the association of heme iron intake, non heme iron intake and menstrual phase with serum ferritin in adolescent girls.

Method : This study used a cross-sectional design study consisted of 50 adolescent girls aged 12-16 years selected by random sampling method. The data taken were heme and non heme iron intake, menstrual phase, and serum ferritin. Heme and non heme iron intake data were obtained by using Semi Quantitative Food Frequency Questionnaire (SQFFQ). Menstrual phase data was average menstrual phase for three months. Serum ferritin and C-Reactive Protein (CRP) measured by Immunosorbent Enzyme-Linked method. Spearman rank test were used to analyzed the data.

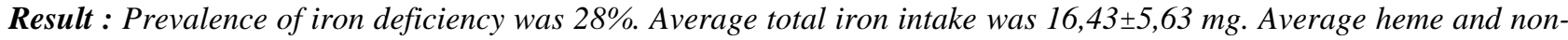

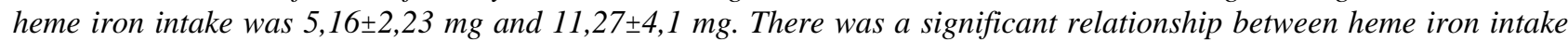
$(p<0.001)$, non-heme iron intake ( $p<0.001)$, total iron intake $(p<0.001)$, menstrual phase $(p=0.012)$ and serum ferritin in adolescent girls.

Conclussion : There was a significant relationship between heme iron intake, non-heme iron intake and menstrual phase and serum ferritin in adolescent girls.
\end{abstract}

Keyword : iron intake, menstrual phase, ferritin serum, adolescent girl

\begin{abstract}
ABSTRAK
Latar Belakang : Remaja putri di Indonesia memiliki asupan zat besi tergolong kurang dimana sumber zat besi didominasi asupan non heme. Biovailabilitas besi non heme dipengaruhi oleh zat yang menghambat penyerapan sehingga berisiko mengalami defisiensi besi. Penelitian ini bertujuan untuk menganalisis hubungan asupan zat besi heme, zat besi non-heme dan fase menstruasi dengan serum feritin remaja putri.

Metode : Penelitian ini menggunakan desain cross-sectional dengan 50 remaja putri berusia 12-16 tahun yang dipilih dengan metode random sampling. Data yang diambil yaitu asupan zat besi heme dan non heme, fase menstruasi dan serum feritin. Data asupan zat besi diperoleh dari kuesioner Semi Quantitative Food Frequency Questionnaire (SQ$F F Q$ ). Data fase menstruasi adalah rata-rata fase menstruasi selama tiga bulan. Serum feritin dan Kadar C-Reactive Protein (CRP) diukur menggunakan metode Immunosorbent Enzyme-Linked). Analisis data menggunakan uji korelasi rank spearman.

Hasil : Prevalensi defisiensi besi ditemukan sebanyak 28\%. Rata-rata asupan besi total 16,43 \pm 5,63 mg. Rata-rata asupan zat besi heme dan non heme sebesar 5,16 $\pm 2,23 \mathrm{mg}$ dan 11,27 $\pm 4,1 \mathrm{mg}$. Terdapat hubungan yang signifikan antara asupan zat besi heme $(p<0,001)$, zat besi non heme $(p<0,001)$, zat besi total $(p<0,001)$ dan fase menstruasi $(p=0,012)$ dengan serum feritin remaja putri.
\end{abstract}

Simpulan : Terdapat hubungan signifikan antara asupan zat besi heme, zat besi non heme dan fase menstruasi dengan serum feritin remaja putri.

Kata Kunci : asupan zat besi, fase mentruasi, serum feritin, remaja putri

\section{PENDAHULUAN}

Masa remaja merupakan masa terjadinya perubahan yang berlangsung cepat dalam hal pertumbuhan fisik, kognitif dan psikososial. Masa remaja ini juga disebut sebagai masa peralihan dari anak-anak menuju remaja yang ditandai dengan banyak perubahan, diantaranya perubahan jaringan lemak tubuh dan perubahan hormon. Remaja awal khususnya remaja putri terjadi peningkatan kebutuhan asupan zat gizi dikarenakan adanya pertumbuhan badan yang pesat (growth spurt) dan adanya proses reproduksi. ${ }^{1}$ Percepatan pertumbuhan yang dialami remaja putri jika tidak diimbangi dengan asupan gizi yang optimal, akan berdampak pada masalah gizi salah satunya adalah anemia defisiensi besi.

Prevalensi anemia defisiensi besi pada remaja putri di wilayah Semarang masih tergolong tinggi. Berdasarkan hasil penelitian tahun 2013 menyebutkan remaja putri mengalami anemia sebanyak $71,4 \% .^{2}$ Penelitian lain yang dilakukan tahun 2017 pada remaja putri di sekolah menengah 
pertama di Semarang Barat menunjukan 58\% siswi mengalami anemia. ${ }^{3}$ Risiko terjadinya defisiensi besi lebih banyak terjadi meskipun belum terkena anemia. Berdasarkan penelitian yang dilakukan tahun $2016 \mathrm{di}$ Spanyol menyebutkan defisiensi besi meningkat pada usia remaja sebanyak $50.2 \%$ dan anemia defisiensi besi sebanyak $7.9 \% .^{4}$ Hasil penelitian lain yang dilakukan tahun 2016 di Semarang menyebutkan 43,59\% remaja putri mempunyai kadar serum feritin rendah yang berarti berisiko mengalami defisiensi besi. $^{5}$

Defisiensi besi didefinisikan sebagai kondisi di mana tidak ada besi yang dapat dimobilisasikan, sehingga hasilnya terjadi ketidakseimbangan besi dalam jangka panjang dan akhirnya mengarah pada terganggunya besi ke jaringan tubuh. ${ }^{6}$ Terdapat tiga tahap anemia defisiensi besi yaitu tahap pertama deplesi besi, tahap kedua disebut defisiensi besi eritropoesis dan tahap ketiga disebut anemia defisiensi besi. Defisiensi besi sendiri terjadi pada tahap awal yaitu deplesi besi yang ditandai dengan penurunan serum feritin. ${ }^{78}$

Pemeriksaan secara biokimia perlu dilakukan untuk mengetahui adanya defisiensi besi secara dini sebelum terjadi anemia defisiensi besi. Serum feritin merupakan biomarker klinis yang dapat digunakan untuk mendeteksi adanya defisiensi besi. Kategori normal serum feritin berada dalam kisaran 15-300 ng/mL. Kriteria World Health Organization (WHO) yang digunakan untuk mendefinisikan adanya penyimpanan besi habis atau defisiensi besi adalah kurang dari $15 \mu \mathrm{g} / \mathrm{L}$ untuk perempuan yang berusia lebih dari 5 tahun. $^{7} 8$

Defisiensi besi yang dialami remaja putri dapat disebabkan oleh rendahnya asupan zat besi terkait dengan nilai bioavailabilitas zat besi pada konsumsi pangan. ${ }^{9}$ Asupan zat gizi yang kurang sehingga menyebabkan cadangan besi dalam tubuh tidak seimbang. ${ }^{10}$ Makanan dari sumber hewani memiliki tingkat bioavailabilitas zat besi yang tinggi. Sebaliknya, makanan dari sumber nabati memiliki tingkat bioavailabilitas zat besi yang rendah. ${ }^{9}$

Berdasarkan pola konsumsi pangan masyarakat, asupan zat besi yang berasal dari konsumsi pangan sehari-hari sulit untuk memenuhi kebutuhan zat besi yang tinggi pada remaja putri. ${ }^{9} \mathrm{Hal}$ ini dikarenakan rata-rata ketersediaan pangan didominasi dari sumber non heme sehingga, konsumsi makanannya lebih banyak mengandung tinggi zat penghambat seperti kalsium, phosvitin dalam kuning telur serta asam fitat, polifenol, tanin, oksalat yang terdapat dalam produk sayuran, kacangkacangan, teh, kopi, coklat dan lainnya. ${ }^{11}$

Fase menstruasi yang tidak teratur pada remaja putri dapat mempengaruhi simpanan besi didalam tubuh. Semakin lama mengalami menstruasi maka semakin banyak darah yang keluar dari dalam dan simpanan zat besi akan berkurang. Ketika simpanan besi habis, kejenuhan trasferrin akan berkurang, jumlah protorpirin yang diubah menjadi heme berkurang dan diikuti dengan menurunnya kadar serum feritin. ${ }^{12}$

Defisiensi besi pada remaja putri akan berdampak buruk bagi perkembangan saraf dan perilaku meliputi penurunan aktivitas motorik, penurunan interaksi sosial dan gangguan fungsi kognitif. ${ }^{13}$ Selain itu, defisiensi besi juga dapat menyebabkan penurunan tingkat kebugaran, daya ingat, daya imun dan daya konsentrasi sehingga berdampak pada kemampuan belajar rendah dan berpengaruh pada prestasi belajar. ${ }^{14}$

Penelitian sebelumya mengenai hubungan status antropometri dan asupan zat gizi dengan serum feritin pada remaja putri serta perbedaan kadar serum feritin pada remaja putri dengan status gizi lebih dan status gizi normal telah dilakukan. Namun, penelitian mengenai asupan zat besi heme, zat besi non heme dan fase menstruasi dengan serum feritin belum pernah dilakukan. Oleh karena itu, penulis tertarik untuk meneliti hubungan asupan zat besi heme, zat besi non heme dan fase menstruasi dengan serum feritin remaja putri.

\section{METODE}

Penelitian ini merupakan penelitian deskriptif analitik dengan pendekatan cross sectional. Penelitian dilaksanakan pada bulan Oktober 2018 hingga Februari 2019 berlokasi di Sekolah Menengah Pertama Negeri 31 Semarang. Pemilihan sampel dikakukan secara random sampling. Jumlah sampel asli dalam penelitian ini sebanyak 47 remaja putri yang didapatkan dari rumus perhitungan besar sampel berdasarkan koefisien korelasi penelitian sebelumnya. Namun, jumlah subjek yang terlibat dalam penelitian ini sebanyak 50 remaja putri.

Kriteria inklusi dalam penelitian ini diantaranya remaja putri usia 12-16 tahun yang terdaftar di Sekolah Menengah Pertama Negeri 31 Semarang, tidak sedang mengalami menstruasi ketika dilakukan pengambilan darah, tidak sedang mengalami sakit atau dalam perawatan dokter, tidak mengkonsumsi obat atau suplemen penambah darah dan tidak memiliki riwayat penyakit kronis seperti tumor, kanker, asam urat, penyakit ginjal kronis, penyakit jantung kronis, Human Immunodeficiency Virus (HIV) dan lain-lain. Selain itu, dikarenakan siklus menstruasi yang tidak teratur setiap bulannya ataupun pendek bagi remaja putri pada masa awal maupun remaja akhir merupakan hal yang normal. Kriteria inklusi dalam penelitian ini juga dipilih dengan subjek sudah mengalami menstruasi minimal 1 tahun. ${ }^{15}$ 
Penelitian ini diawali dengan melakukan penelitan pendahuluan pada bulan Oktober 2018 yaitu dengan menyebarkan kalender menstruasi dan memberikan kuesioner identitas subjek penelitian. Penyebaran kalender menstruasi dilakukan untuk mencatat data fase menstruasi. Fase menstruasi atau lama menstruasi dihitung dari awal keluarnya darah saat menstruasi hingga pengeluaran darah tepat berhenti keluar. Data fase menstruasi diambil apabila sudah berjalan tiga kali fase menstruasi atau selama tiga bulan yang kemudian akan dirata-rata. Hal tersebut dilakukan untuk melihat keteraturan fase menstruasi. ${ }^{16}$ Kuesioner identitas subjek dalam penelitian ini berisi nama, usia, tanggal lahir, alamat, riwayat penyakit, konsumsi suplemen atau obatobatan tertentu, usia menarche dan lain lain.

Setelah memenuhi kriteria inklusi, subjek kemudian diberikan informed consent sebagai bentuk persetujuan mengikuti penelitian. Subjek terpilih dikumpulkan untuk melakukan pengukuran antropometri berupa pengukuran tinggi badan menggunakan microtoise dan penimbangan berat badan menggunakan timbangan digital dengan ketelitian $0,1 \mathrm{~kg}$. Data antropometri kemudian diolah untuk mendapatkan data status gizi subjek. Variabel status gizi ditentukan dengan indeks IMT/U menggunakan nilai z-score. Subjek dikategorikan sangat kurus apabila nilai z-score <-3 SD, kurus -3 SD sampai <-2 SD, normal -2 SD sampai $1 \mathrm{SD}$, gemuk $>1$ SD sampai $2 \mathrm{SD}$, dan obesitas $>2 \mathrm{SD} .{ }^{17}$

Subjek kemudian diwawancara untuk memperoleh data asupan zat besi subjek. Data asupan zat besi diperoleh dari 1 kali wawancara kepada subjek menggunakan Semi Quantitative-Food Frequency Questionnaire (SQFFQ) untuk asupan 1 bulan terakhir. Data yang diperoleh dalam ukuran rumah tangga kemudian dikonversikan kedalam satuan gram selanjutnya dianalisis dengan menggunakan software nutrisurvey 2007.

Data asupan zat besi dibagi menjadi asupan besi heme, asupan zat besi non-heme dan asupan zat besi total. Asupan zat besi heme yang diperoleh dari sumber makanan hewani dan asupan zat besi nonheme diperoleh dari sumber makanan nabati. Data asupan masing-masing zat besi heme dan non heme kemudian dibandingkan dengan Angka Kecukupan Gizi (AKG) tahun 2013 sebesar 26 mg. Hasilnya akan diperoleh presentase (\%) kecukupan besi heme dan non heme. Data asupan besi total merupakan jumlah antara asupan besi heme dan besi non heme. Data asupan zat besi total tersebut kemudian dibandingkan dengan Angka Kecukupan Gizi (AKG) tahun 2013 sebesar $26 \mathrm{mg}$. Hasilnya diperoleh presentase (\%) kecukupan asupan besi total. Asupan zat besi dikatakan kurang apabila hanya memenuhi $<80 \%$, cukup apabila memenuhi $80-110 \%$, dan lebih apabila memenuhi $>110 \%$ dari total kebutuhan harian. ${ }^{18}$

Pengambilan darah berupa kadar serum feritin dan C-Reactive Protein diambil sebanyak $3 \mathrm{cc}$ oleh petugas laboratorium. Metode yang digunakan adalah immunosorbent enzyme-linked oleh petugas laboratorium. Kadar CRP merupakan salah satu parameter uji umum yang digunakan untuk menilai, mendiagnosis, dan memperkirakan adanya peradangan atau infeksi. ${ }^{19}$ Kadar CRP yang diukur dalam penelitian ini bernilai negatif, hal tersebut berarti rendahnya serum feritin pada subjek menandakan adanya defisiensi besi.

Analisis statistik menggunakan software statistik. Analisis univariat dilakukan untuk mendeskripsikan karakteristik subjek, kadar serum feritin, asupan besi heme, asupan besi non heme, total asupan besi, fase menstruasi dan status gizi. Data tersebut diuji kenormalannya menggunakan uji Kolmogorov-smirnov. Analisis bivariat menggunakan uji Rank Spearman untuk mengetahui hubungan masing-masing variabel asupan besi heme, asupan besi non heme, total asupan besi, fase menstruasi dan status gizi terhadap serum feritin remaja putri.

\section{HASIL \\ Karakteristik Subjek}

Tabel 1. Karakteristik Subjek Penelitian

\begin{tabular}{|c|c|c|c|}
\hline \multicolumn{2}{|c|}{ Variabel } & $\mathbf{n}$ & $\%$ \\
\hline \multicolumn{4}{|c|}{ Umur } \\
\hline - & 13 tahun & 8 & 16 \\
\hline - & 14 tahun & 31 & 62 \\
\hline - & 15 tahun & 11 & 22 \\
\hline \multicolumn{4}{|c|}{ Menarche } \\
\hline - & 10 tahun & 5 & 10 \\
\hline - & 11 tahun & 22 & 44 \\
\hline - & 12 tahun & 18 & 36 \\
\hline - & 13 tahun & 5 & 10 \\
\hline \multicolumn{4}{|c|}{ IMT/U } \\
\hline - & Kurang & 1 & 2 \\
\hline - & Normal & 34 & 68 \\
\hline- & Gemuk & 12 & 24 \\
\hline - & Obesitas & 3 & 6 \\
\hline \multicolumn{4}{|c|}{ Asupan Zat Besi } \\
\hline - & Kurang $(<80 \%)$ & 29 & 58 \\
\hline - & Cukup (80-110\%) & 21 & 42 \\
\hline \multicolumn{4}{|c|}{ Fase Menstruasi } \\
\hline - & Normal (3-8 hari) & 36 & 72 \\
\hline - & Panjang ( $>9$ hari) & 14 & 28 \\
\hline \multicolumn{4}{|c|}{ Serum Feritin } \\
\hline - & Normal $(10-200 \mathrm{ng} / \mathrm{ml})$ & 36 & 72 \\
\hline - & Kurang $\quad(<10 \mathrm{ng} / \mathrm{ml})$ & 14 & 28 \\
\hline
\end{tabular}


Data Karakteristik subjek penelitian terdiri dari usia, menarche, status gizi, asupan zat besi, fase menstruasi dan serum feritin ditampilkan pada tabel 1, diketahui subjek rata-rata berusia 14 tahun (62\%). Adapun subjek mengalami menarche rata-rata berusia 11 tahun dan 12 tahun yaitu sebanyak $44 \%$ dan $36 \%$. Mayoritas subjek memiliki status gizi normal yaitu sebanyak 34 subjek (68\%). Namun, masih ditemukan subjek dengan status gizi kurang sebanyak $2 \%$, gemuk sebanyak $24 \%$ dan obesitas sebanyak 6\%. Sebagian besar subjek memiliki asupan zat besi termasuk kurang yaitu sebanyak 29 subjek $(58 \%)$. Selain itu, rata-rata subjek memiliki fase menstruasi normal sebanyak 36 subjek (72\%). Kadar serum feritin subjek penelitian termasuk dalam kategori kurang yaitu sebanyak 14 subjek (28\%).
Data nilai rerata, standar deviasi, median, nilai minimal dan maksimal asupan zat besi, fase menstruasi dan status gizi dijelaskan pada tabel 2, nilai median asupan besi sebesar $15,75 \mathrm{mg}$ dimana masih kurang dari AKG zat besi yaitu $26 \mathrm{mg}$. Nilai median asupan besi non-heme lebih tinggi dibandingkan dengan asupan besi heme yaitu sebesar $10,95 \mathrm{mg}$, sedangkan asupan heme sebesar 4,45 mg. Nilai median pada presentase asupan besi total sebesar $61 \%$ dimana masih tergolong kurang dari kategori yang ditetapkan yaitu $80-110 \%$. Pada presentase asupan besi non-heme mempunyai nilai median yang lebih tinggi sebesar $42 \%$ dibandingkan dengan presentase asupan besi heme sebesar 17,5\%.

Tabel 2. Asupan Zat Besi, Fase Menstruasi, IMT/U Dan Serum Feritin

\begin{tabular}{lllll}
\hline Variabel & Minimal & Maksimal & Mean \pm SD & Median \\
\hline Asupan Besi Total (mg) & 6,5 & 26,3 & $16,43 \pm 5,63$ & 15,75 \\
Asupan Besi Heme (mg) & 1,7 & 10,7 & $5,16 \pm 2,23$ & 4,45 \\
Asupan Besi Non Heme (mg) & 3,7 & 22,1 & $11,27 \pm 4,1$ & 10,95 \\
Presentase Kecukupan Asupan Besi Total (\%) & 25 & 101 & $63,28 \pm 21,69$ & 61 \\
Presentase Kecukupan Asupan Besi Heme (\%) & 7 & 41 & $19,84 \pm 8,51$ & 17,5 \\
Presentase Kecukupan Asupan Besi Non Heme (\%) & 14 & 85 & $43,38 \pm 15,82$ & 42 \\
Fase Menstruasi (Hari) & 3 & 10 & $7 \pm 1,89$ & 7 \\
IMT/U (SD) & $-2,12$ & 2,15 & $0,44 \pm 1,08$ & 0,64 \\
Serum Feritin (ng/ml) & 3,49 & 104,72 & $24,67 \pm 20,09$ & 16,9 \\
\hline
\end{tabular}

Nilai rerata fase menstruasi sebesar 7 hari termasuk normal. Namun terdapat nilai maksimal sebesar 10 hari yang termasuk dalam kategori panjang. Selain itu, nilai rerata serum feritin sebesar $24,67 \mathrm{ng} / \mathrm{ml}$ termasuk normal.

Tabel 3. Hubungan Asupan Zat Besi, Fase Menstruasi dan Status Gizi dengan Serum Feritin

\begin{tabular}{lcc}
\hline Variabel & $\boldsymbol{r}$ & $\boldsymbol{p}$ \\
\hline Asupan Besi Heme (mg) & 0,639 & $<0,001^{\mathrm{a}}$ \\
Asupan Besi Non Heme (mg) & 0,608 & $<0,001^{\mathrm{a}}$ \\
Asupan Besi Total (mg) & 0,648 & $<0,001^{\mathrm{a}}$ \\
Fase Menstruasi (hari) & $-0,354$ & $0,012^{\mathrm{a}}$ \\
IMT/U (SD) & 0,085 & $0,558^{\mathrm{a}}$ \\
\hline
\end{tabular}

a.Uji Rank Spearman

\section{Hubungan Asupan Zat Besi, Fase menstruasi dan Status Gizi dengan Serum Feritin}

Data hubungan asupan besi, fase menstruasi dan status gizi dengan serum feritin ditampilkan pada tabel 3 .

Berdasarkan tabel 3, asupan besi heme, asupan besi non-heme, asupan besi total memiliki koefisien korelasi yang kuat dan bernilai positif (+) yang berarti semakin tinggi asupan besi maka semakin tinggi serum feritin. Pada fase menstruasi koefisien korelasi cukup dan bernilai negatif (-) yang berarti semakin tinggi fase menstruasi semakin maka akan semakin rendah serum feritin. Sedangkan, pada IMT/U koefisien korelasi sangat lemah dan bernilai positif (+) yang berarti semakin tinggi IMT/U maka semakin tinggi serum feritin.

Terdapat hubungan signifikan antara asupan besi heme $(p<0,001)$, Asupan besi non-heme ( $p<$ $0,01)$, asupan besi total $(p<0,01)$ dan fase menstruasi $(p=0,012)$ dengan kadar serum feritin remaja putri. Tidak terdapat hubungan status gizi berdasarkan IMT/U dengan kadar serum feritin remaja putri ( $p$ $>0,05)$.

Hasil penelitian dijelaskan pada tabel 4, terdapat 29 subjek dengan asupan besi kurang diantaranya sebanyak 13 subjek $(44,8 \%)$ mempunyai kadar serum feritin kurang dan 16 subjek $(55,2 \%)$ mempunyai kadar serum feritin normal. Sebanyak 14 subjek memiliki fase menstruasi panjang diantaranya 7 subjek (50\%) mempunyai kadar serum feritin yang kurang. Pada IMT/U sebanyak 14 subjek memiliki kadar serum feritin yang kurang dengan rata-rata sebanyak 8 subjek (23.5\%) memiliki status gizi normal. 
Tabel 4. Karakteristik Subjek dengan Serum Feritin

\begin{tabular}{|c|c|c|}
\hline \multirow[t]{2}{*}{ Variabel } & \multicolumn{2}{|c|}{ Serum Ferritin } \\
\hline & Kurang (n (\%)) & Normal (n (\%)) \\
\hline \multicolumn{3}{|l|}{ Asupan Besi } \\
\hline - $\quad$ Kurang & $13(44,8 \%)$ & $16(55,2 \%)$ \\
\hline - Cukup & $1(4,8 \%)$ & $20(95,2 \%)$ \\
\hline \multicolumn{3}{|l|}{ Fase Menstruasi } \\
\hline - $\quad$ Panjang & $7(50 \%)$ & $7(50 \%)$ \\
\hline - Normal & & $36(100 \%)$ \\
\hline \multicolumn{3}{|l|}{ IMT/U } \\
\hline - Kurang & $1(100 \%)$ & \\
\hline - Normal & $8(23,5 \%)$ & $26(76,5 \%)$ \\
\hline - Gemuk & $4(33,3 \%)$ & $8(66,7 \%)$ \\
\hline - $\quad$ Obesitas & $1(33,3 \%)$ & $2(66,7 \%)$ \\
\hline
\end{tabular}

\section{PEMBAHASAN}

Prevalensi defisiensi besi pada remaja putri sebesar 28\%. Prevalensi ini lebih kecil dibandingkan penelitian yang dilakukan tahun 2011 kepada remaja putri pondok pesantren di Semarang yaitu sebesar $32.4 \% .{ }^{20}$ Selain itu, prevalensi penelitian ini juga lebih kecil dibandingkan dengan penelitian yang dilakukan tahun 2016 pada remaja putri di Kota Semarang yaitu sebesar $43.59 \%{ }^{5}$

Faktor yang menyebabkan adanya perbedaan hasil penelitian ini dapat dipengaruhi oleh tingkat pengetahuan subjek. Hal ini terkait dengan lokasi penelitian subjek sering jadikan sebagai tempat penelitian maupun edukasi kesehatan terutama di bidang gizi yang dilakukan dari pihak puskesmas setempat ataupun pihak peneliti lain. Edukasi yang sering diberikan kepada subjek penelitian yakni edukasi mengenai masalah gizi seperti anemia. Pemberian edukasi menyebabkan tingkat pengetahuan subjek menjadi meningkat. Selain itu, pemberian edukasi juga mempunyai pengaruh terhadap peningkatan motivasi dan perubahan perilaku subjek untuk memperbaiki masalah kesehatannya. ${ }^{21} 22$ Salah satunya dengan peningkatan pengetahuan akan pentingnya mengkonsumsi asupan zat besi sehingga sebagian besar kebutuhan asupan zat besi subjek menjadi terpenuhi dan risiko terjadinya defisiensi besi menjadi berkurang. ${ }^{21}$

Asupan zat besi subjek sebagian besar tergolong kurang yaitu sebanyak 29 subjek (58\%). Asupan zat besi yang kurang pada sebagian besar subjek disebabkan oleh frekuensi, jumlah dan jenis makanan yang dikonsumsi subjek kurang beragam. Rata-rata subjek diketahui mempunyai frekuensi makan dua kali sehari dengan jumlah asupan makanan yang sedikit. Selain itu, tingkat asupan zat besi kurang pada subjek penelitian berasal dari asupan besi non-heme.

Terdapat hubungan yang signifikan antara asupan besi non-heme dengan serum feritin remaja putri $(p<0,001)$. Rata-rata asupan besi non-heme subjek sebesar $11,27 \mathrm{mg}$ dimana hanya memenuhi
43\% kebutuhan. Asupan besi non-heme merupakan sumber bahan makanan nabati. Rata-rata subjek lebih sering mengkonsumsi sumber bahan makanan yang berasal dari produk nabati dibandingkan hewani seperti sayuran dan kacang-kacangan. Asupan besi non-heme sendiri memiliki tingkat absorbsi dan bioavailabilitas rendah. ${ }^{23}$ Bioavailabilitas besi nonheme dipengaruhi oleh berbagai komponen diet yang dapat menghambat atau meningkatkan penyerapan. Penyerapan zat besi non-heme dapat dihambat oleh bahan makanan yang mengandung asam fitat yang biasanya ditemukan dalam sayuran dan kacangkacangan. ${ }^{24} 25$

Di samping itu, terdapat juga bahan makanan yang dapat meningkatkan penyerapan zat besi nonheme. Kelompok bahan makanan peningkat penyerapan zat besi adalah bahan makanan yang mempunyai fungsi sebagai bahan makanan yang akan memperbesar penyerapan zat besi dari dalam makanan yang dikonsumsi sehari-hari. ${ }^{1}{ }^{24}$ Bahan makanan yang dapat meningkatkan penyerapan zat besi diantaranya bahan makanan yang mengandung Asam organik (asam sitrat, malat dan laktat), vitamin A, $\beta$-karoten dan vitamin C. ${ }^{24}$

Salah satu kandungan dalam vitamin yang sangat membantu penyerapan besi non-heme adalah vitamin C. Kandungan vitamin C ini dapat mereduksi besi ferri menjadi ferro dalam usus halus sehingga mudah diabsorpsi dengan menghambat pembentukan hemosiderin yang sukar dimobilisasi untuk membebaskan besi bila diperlukan. Absorpsi besi dalam bentuk non-heme meningkat empat kali lipat bila ada vitamin C. Akibatnya, risiko terjadinya defisiensi zat besi dapat dihindari. ${ }^{20}$

Hasil analisis dalam penelitian ini juga menunjukan terdapat hubungan yang signifikan antara asupan besi heme dengan serum feritin remaja putri ( $\mathrm{p}<0,001)$. Rata-rata asupan besi heme remaja putri sebesar 5,16 mg dimana hanya memenuhi $20 \%$ kebutuhan. Asupan besi heme sendiri memiliki tingkat absorbsi dan bioavailabilitas tinggi. Hal ini dikarenakan zat besi heme tersedia dalam bentuk besi 
$\mathrm{Fe}^{2+}$ (ferro) yang langsung dapat di absorbsi dan tidak dipengaruhi zat yang dapat menghambat penyerapan. ${ }^{26}$ Asupan zat besi heme pada subjek diketahui lebih sedikit dibandingkan dengan asupan zat besi non-heme. Hal ini dikarenakan subjek mengonsumsi sumber bahan makanan hewani seperti telur ayam, daging ayam dan ikan hanya beberapa kali dalam seminggu atau dengan jenis, jumlah dan frekuensi yang sedikit.

Hasil analisis menunjukkan terdapat hubungan signifikan asupan zat besi dengan serum ferritin remaja putri $(p<0,001)$. Penelitian ini diketahui terdapat 29 subjek mempunyai asupan besi yang kurang diantaranya 13 subjek $(44,8 \%)$ memiliki kadar serum feritin yang rendah. Keterkaitan asupan zat besi dengan serum feritin dapat dijelaskan bahwa di dalam tubuh besi disimpan dalam hepatosit dalam bentuk feritin dan hemosiderin. Feritin adalah protein lain yang penting dalam metabolisme besi. Pada kondisi normal, feritin meyimpan besi yang dapat diambil kembali untuk digunakan sesuai kebutuhan. Jika terdapat jumlah asupan zat besi dari makanan kurang, maka akan terjadi ketidakseimbangan zat besi di dalam tubuh. Jumlah cadangan zat besi dalam tubuh berkurang dan diikuti terjadinya defisiensi besi yang ditandai dengan penurunan serum feritin. ${ }^{27}$

Sisanya sebanyak 16 subjek $(55,2 \%)$ mempunyai asupan besi kurang dengan serum ferritin yang normal. Adanya serum feritin normal pada subjek dengan asupan besi heme dan non heme yang kurang dapat terjadi. Hal ini dapat dikarenakan ratarata subjek mengonsumsi bahan makan yang dapat meningkatkan penyerapan zat besi seperti yang terdapat dalam buah-buahan. Selain itu, subjek juga mengonsumsi sumber makanan hewani seperti daging, ikan, dan unggas. Namun, frekuensi konsumsi makanan tersebut hanya beberapa kali dalam seminggu. Makanan dari sumber hewani tergolong dalam zat besi heme yang bertindak sebagai Meat fish poultry factor (MFP factor) yang berperan dalam meningkatkan penyerapan zat besi non heme. ${ }^{28}$ Selain itu, zat besi heme memiliki tingkat absorbsi dan bioavailabilitasnya tinggi. ${ }^{29}{ }^{24}$ Penelitian ini, meskipun kadar serum feritin normal, namun beresiko mengalami defisiensi besi dikarenakan angka kadar serum feritin terebut mendekati ambang batas yang normal.

Terdapat 1 subjek $(4,8 \%)$ mempunyai asupan besi yang cukup dengan serum feritin yang rendah. Meskipun demikian, asupan besi yang cukup dalam penelitian ini menyebabkan rendahnya serum feritin. Hal ini dikarenakan sebagian besar asupan besi subjek berasal dari asupan besi non-heme dimana tingkat absorpsi dan bioavailabilitasnya rendah. ${ }^{23}$ Absorpsi besi dari sumber non-heme memerlukan proses metabolisme tersendiri karena sumber besi non-heme kebanyakan tersedia dalam bentuk teroksidasi $\mathrm{Fe}^{3+}$ (ferri) sehingga harus di reduksi terlebih dahulu menjadi $\mathrm{Fe}^{2+}$ (ferro) oleh $\mathrm{HCl}$ di dalam lambung. ${ }^{50}$ Selain itu, bioavailabilitas besi non-heme dipengaruhi oleh berbagai komponen diet yang dapat menghambat penyerapan zat besi didalam tubuh. ${ }^{24}$

Hasil analisis menunjukkan terdapat hubungan yang signifikan antara fase menstruasi dengan serum feritin remaja putri $(p<0,012)$. Terdapat 14 subjek mempunyai fase menstruasi panjang yaitu sebanyak 7 subjek (50\%) dengan serum feritin yang rendah. Hal ini dapat terjadi karena pengeluaran darah selama menstruasi menunjukan kehilangan simpanan zat besi secara cepat sesuai dengan lama menstruasi (fase menstruasi) dan banyaknya darah yang keluar. Fase menstruasi yang panjang menyebabkan semakin banyak darah yang keluar dan simpanan zat besi akan berkurang. ${ }^{12}$ Ketika simpanan besi habis, kejenuhan trasferrin akan berkurang, jumlah protorpirin yang diubah menjadi heme berkurang dan diikuti dengan menurunnya kadar serum feritin. Ketika remaja mengalami defisiensi besi, cadangan besi dalam tubuh akan semakin menipis sehingga dapat berlanjut ke anemia defisiensi besi. ${ }^{31} 32$

Sisanya sebanyak 7 subjek (50\%) memiliki fase menstruasi panjang dengan serum feritin yang normal. Rata-rata subjek dalam penelitian ini juga mempunyai asupan besi heme dan non-heme yang kurang. Hal ini bertentangan dengan teori dimana seharusnya subjek memiliki serum feritin yang juga rendah. Meskipun demikian, angka kadar serum feritin pada penelitian ini juga mendekati batas normal yang ditetapkan dimana mempunyai risiko tinggi mengalami defisiensi besi. Kadar serum feritin yang normal meskipun asupan besi heme dan nonheme kurang diduga karena subjek mengonsumsi kelompok asupan bahan makanan yang dapat membantu meningkatkan penyerapan zat besi seperti yang terdapat dalam buah-buahan, ikan, telur dan daging ayam. ${ }^{19}$

Defisiensi besi pada remaja putri salah satunya dapat disebabkan oleh adanya menstruasi setiap bulan. Remaja putri memerlukan lebih banyak zat besi dari pada pria, dikarenakan harus menggantikan jumlah zat besi yang hilang selama periode menstruasi. Selama menstruasi remaja putri kehilangan sekitar $1 \mathrm{mg}$ zat besi setiap harinya. Ketika dalam keadaan menstruasi remaja putri perlu mengonsumsi asupan zat gizi yang cukup untuk menghindari risiko terjadinya defisiensi besi. ${ }^{33}$ Jika konsumsi asupan makanan yang mengandung zat besi tidak tercukupi akan sangat rentan mengalami defisiensi besi sehingga, diperlukan suplemen tablet 
besi $(\mathrm{Fe})$ sebagai tindakan pencegahan sebelum terjadi anemia. ${ }^{34}$

Variabel perancu dalam penelitian ini adalah status gizi. Analisis statistik menunjukan status gizi memiliki hubungan yang tidak signifikan dengan serum feritin remaja putri. Hal ini dikarenakan status gizi kurang maupun gemuk dan obesitas sama-sama memiliki risiko terkena defisiensi besi.

Hasil analisis menunjukkan terdapat 1 subjek (100\%) mempunyai status gizi kurang dengan serum feritin yang rendah. Status gizi kurang pada remaja putri merupakan faktor risiko terjadinya penipisan besi (iron depletion). ${ }^{35}$ Underweight mengakibatkan peningkatan aktivitas enzim glikolitik seperti hexokinase, kinase piruvat dan glukosa 6-fosfat dehidrogenase $\left(\mathrm{G}_{6} \mathrm{PD}\right)$ mengubah permeabilitas membran, sehingga menyebabkan pemecahan sel darah merah. Hal ini ditandai dengan kadar serum feritin yang cenderung rendah. ${ }^{35} 36$

Hasil analisis menunjukkan terdapat sebanyak 4 subjek $(33,3 \%)$ dengan status gizi gemuk dan 1 subjek $(33,3 \%)$ dengan status gizi obesitas mempunyai serum feritin yang rendah. Penelitian ini menemukan status gizi gemuk dan obesitas masih tergolong tingkat rendah sehingga, berisiko mengalami defisiensi besi. Hal ini dikarenakan jaringan adiposit di dalam tubuh belum mengalami inflamasi kronik derajat rendah. Adanya inflamasi kronik derajat rendah ini juga belum menyebabkan sekresi hepsidin meningkat. ${ }^{37}$ Namun, status gizi lebih atau obesitas tingkat tinggi akan menyebabkan produksi hepsidin meningkat dan akan masuk ke dalam sirkulasi untuk mengatur penyediaan zat besi. ${ }^{38}$ Mekanisme ini akan menghambat penyerapan zat besi pada saluran cerna dan menghambat pelepasan zat besi dari makrofag ke dalam plasma. ${ }^{39} \mathrm{Hal} \mathrm{ini}$ ditandai dengan kadar serum feritin cenderung akan meningkat. ${ }^{40} 38$

\section{SIMPULAN}

Terdapat hubungan yang signifikan antara asupan zat besi heme, zat besi non-heme, zat besi total dan fase menstruasi dengan serum feritin remaja putri.

\section{SARAN}

Kecukupan asupan zat besi non heme lebih tinggi dibandingkan dengan asupan zat besi heme. Subjek hendaknya meningkatkan frekuensi makan dan konsumsi makanan dengan jenis yang bervariasi. Subjek juga hendaknya mengonsumsi makanan yag dapat meningkatkan penyerapan zat besi seperti makanan tinggi protein hewani seperti daging, ikan, dan unggas. Selain itu, subjek sebaiknya membatasi makanan atau minuman yang dapat menghambat penyerapan zat besi seperti asam fitat, tanin, polifenol, oksalat yang terdapat pada sayuran, kacangan-kacangan, teh, kopi, coklat dan lain-lain.

Kehilangan darah saat menstruasi dapat menyebabkan remaja putri rentan mengalami defisiensi besi. Subjek sebaiknya mengonsumsi asupan zat besi yang cukup pada saat terjadi menstruasi. Selain itu, jika konsumsi asupan zat besi tidak cukup maka diperlukan konsumsi suplemen besi $(\mathrm{Fe})$ untuk mengimbangi kehilangan besi saat terjadi menstruasi.

\section{DAFTAR PUSTAKA}

1. Andriani M, Wirjatmadi B., 2012. Peranan Gizi dam Siklus Kehidupan. Di dalam: Hardinsyah, Supariasa IDN. Ilmu Gizi : Teori dan Aplikasi. Jakarta: Penerbit Buku Kedokteran EGC; 2016. 160-161 p.

2. Mariana W, Khafidhoh N. Hubungan Status Gizi dengan Kejadian Anemia Pada Remaja Putri di SMK Swadaya Wilayah Kerja Semarang Tahun 2013. J Kebidanan. 2013;2(4):35-42.

3. Aulia GY, Udiyono A, Saraswati LD, Adi MS. Gambaran Status Anemia Pada Remaja Putri Di Wilayah Pegunungan Dan Pesisir Pantai. J Kesehat Masy. 2017;5:193-200.

4. Urrechaga E, Urrechaga E. Prevalence of Iron Deficiency in Healthy Adolescents. J Ann Nutr Disord Ther Open. 2017;3(2):1-6.

5. Putri NMG, Probosary E. Perbedaan Kadar Serum Ferritin Remaja Putri Status Gizi Normal dan Status Gizi Lebih. J Nutr Coll. 2016;6:393-401.

6. Charles C V. Iron Deficiency Anemia: A Public Health Problem of Global Proportions. J Public Health. 2012;109-30.

7. World Health Organization. Serum Ferritin Concentrations for the Assessment of Iron Status and Iron Deficiency In Populations. Vitamin and Mineral Nutrition Information System. WHO. 2011;1-5.

8. World Health Organization. Assessing the Iron Status of Populations Second Edition: Including Literature Reviews. Geneva; 2007. 80-87 p.

9. Briawan D, Adrianto Y, Ernawati D, Syamsir E, Aries M. Konsumsi Pangan, Bioavailabilitas Zat Besi dan Status Anemia Siswi Di Kabupaten Bogor. IPB. 2012;12(1):61-9.

10. World Health Organization. Haemoglobin Concentration for the Diagnosis of Anemia and Assesment of Severity. Geneva; 2011. 13-21 p.

11. Young I, Parker HM, Rangan A, Prvan T, Cook RL, Donges CE, et al. Association Between Haem and Non-Haem Iron Intake and Serum Ferritin in Healthy Young Women. Nutrients. 2018;10(1):113.

12. Gibney, Michael, Margetts B, Kearney J, Lenore A. Gizi Kesehatan Masyarakat. Jakarta: Penerbit Buku Kedokteran EGC; 2009. 102-105 p.

13. Irsa L. Gangguan Kognitif pada Anemia Defisiensi 
Besi. Sari Pediatr. 2017;4(3):114-8.

14. Herlina. Mengatasi Masalah Anak dan Remaja Melalui Buku. Bandung: Pustaka Cendikia Utama; 2013. 21-22 p.

15. Kusmiran E. Kesehatan Reproduksi Remaja dan Wanita. Jakarta Selatan: Salemba Media; 2012. 56$57 \mathrm{p}$.

16. Nizomy R. Mekanisme Fisiologis Pendarahan Haid. J Berk Kedokt. 2002;2(1):7-9.

17. Kemenkes RI. Standar Penilaian Status Gizi Anak. Jakarta: Direktoral Jendral Bina Gizi dan Kesehatan Ibu dan Anak; 2011. 4 p.

18. Hardinsyah, Riyadi H, Napitupulu V. Kecukupan Energi, Protein, Lemak, Karbohidrat, Vitamin dan Mineral. J Gizi FK UI. 2013;1-26.

19. Chandrashekara S. C - Reactive Protein: An Inflammatory Marker with Specific Role in Physiology, Pathology, and Diagnosis. J Rheumatol Clin Immunol. 2014;2(S1).

20. Adhist Anindya Putri. Hubungan Status Antropometri dan Asupan Gizi dengan Kadar HB dan Ferritin Remaja Putri [Tesis]. Semarang: Universitas Diponegoro; 2011.

21. Marfuah D, Kusudaryati DPD. Efektifitas Edukasi Gizi Terhadap Perbaikan Asupan Zat Besi Pada Remaja Putri. J Profesi. 2016;14(1):5-9.

22. Sefaya KT, Nugraheni SA, Rahayuning D. Pengaruh Pendidikan Gizi Terhadap Pengetahuan Gizi dan Tingkat Kecukupan Gizi Terkait Pencegahan Anemia Remaja (Studi Pada Siswa Kelas XI SMA Teuku Umar Semarang). J Kesehat Masy. 2017;5(1):272-82.

23. Gropper SS, Smith JL GJ. Advanced nutrition and human mebolism. Adams P, Lustig A, Feldman E, Downs E, editors. Amerika Serikat: Wadsworth, Cengage Learning; 2009. 470-472 p.

24. Posen J. Iron and Vegetarian Diets. Med J Aust. 2013;199(4):S11-6.

25. Nurhidayah Husnah, Rahayu Indriasari NJ. Hubungan Makanan Sumber Heme dan Non Heme Terhadap Kadar HB Remaja Putri SMA 10 Makassar Tahun 2014 [Tesis]. Sumatra: Universitas Hasanuddin. 2014.

26. Jamshidi L, Karimi L, Seif A, Vazini H. The Relationship between Anthropometric Factors and Iron Deficiency Anemia Factors. Nov Biomed [Internet]. 2017;5(2):59-64. Available from: http://search.ebscohost.com/login.aspx?direct=tru $\mathrm{e} \& \mathrm{db}=\mathrm{a} 9 \mathrm{~h} \& \mathrm{AN}=122750100 \&$ site $=$ ehost-live

27. Hendra A, Rahmad A. Pengaruh Asupan Protein dan Zat Besi ( $\mathrm{Fe}$ ) terhadap Kadar Hemoglobin pada Wanita Bekerja. J Kesehat. 2017;viii(3):321-
5.

28. Husnah $\mathrm{N}$, Indriasari $\mathrm{R}$, Jafar $\mathrm{N}$. Hubungan Makanan Sumber Heme dan Non Heme Terhadap Kadar Hb Remaja Putri SMA 10 Makassar Tahun 2014 [Tesis]. Sumatra: Universitas Hasanuddin; 2014.

29. Diana FM. Fungsi dan Metabolisme Protein dalam Tubuh Manusia. J Kesehat Masy. 2010;4(1):4752.

30. Burke RM, Leon JS, Suchdev PS. Identification, prevention and treatment of iron deficiency during the first 1000 days. J Nutrients. 2014;6(10):4093114.

31. Arisman. Gizi dalam Daur Kehidupan. Jakarta: Penerbit Buku Kedokteran EGC; 2002. 145-147 p.

32. Wahyuni AS. Anemia Defisien Besi Pada Balita [Tesis]. Sumatra: Universitas Sumatra Utara; 2004.

33. Sinaga E, Saribanon N, Suprihatin, Saadah N, Salamah U, Murti YA, et al. Manajemen Kesehatan Menstruasi. Jakarta: Global One; 2017. 77-80 p.

34. Permatasari T. Pengaruh Program Pemberian Tablet Tambah Darah (TTD) Terhadap Perbaikan Status Besi Pada Remaja Putri Di Kota Bogor [Tesis]. Bogor: Institut Pertanian Bogor; 2017.

35. Sumarmi S, Puspitasari N, Handajani R, Wirjatmadi B. Underweight as a risk factor for Iron depletion and Iron- Deficient erythropoiesis among young women in Rural Areas of East Java, Indonesia. Malays J Nutr. 2016;22(2):219-32.

36. Macdougall, Moodley, Eyberg, Quirk. Mechanism of Anemia in Protein-Energy Malnutrition in Johannesburg. Am J Clin Nutr. 1982;32:35.

37. Hendarto A, Febriyanto R, Kaban RK. Defisiensi Besi dan Anemia Defisiensi Besi pada Anak Remaja Obesitas. J Sari Pediatr. 2018;20(1):1.

38. Silverberg, Chernin, Schwart. Should a Search for Iron Deficiency be Part Of the Regular Screening in All Patient, whether Anemia or not?. J Hemotology Tromboembolic Dis. 2014;2(5).

39. Ridha NR, Daud D. Hubungan Kadar Hepcidin dengan Status Besi pada Inflamasi Akibat Obesitas. J Sari Pediatr. 2014;16(3):161-6.

40. Gartner A, Berger J, Bour A, Ati J El, Traissac P, Landais E, et al. Assessment of iron deficiency in the context of the obesity epidemic: Importance of correcting serum ferritin concentrations for inflammation. Am J Clin Nutr. 2013;98(3):821-6. 